\title{
ANMELDELSER
}

MIKKEL RYTTER: Family Upheaval. Generation, Mobility, and Relatedness among Pakistani Migrants in Denmark. Oxford: Berghahn Books 2013. 234 sider. ISBN 978-0-85745-939-8. Pris: \$ 75.

Mikkel Rytters monografi er solidt håndværk. Her skrives med antropologisk indsigt og overblik. Læseren føres med forfatteren ind i nære sociale relationer, hvorfra familieliv, verdenssyn, bekymringer og fællesskaber får ord at blive formidlet igennem. At vokse op, blive voksen og ældes med referencer, forbindelser og henvendelser til og fra Pakistan både rammesætter og overskrider individuelle liv. Det gælder i intime forhold som valg af ægtefælle og i begivenhedsrige manifestationer, der adresserer globalt ansvar og nationalstatslig anerkendelse. Dette vises i monografien gennem en række etnografiske greb, der i udgangspunktet er klassiske, men som i hænderne på etnografen Mikkel Rytter pudses af og løfter materialet. Særlig gennemført bliver det i situationsanalysen af det store jordskælv, der rystede Kashmir i 2005. Her beskrives, hvorledes pakistanskdanske læger făr mulighed for samlet at handle som pakistansk diaspora. Penge indsamles, læger rejser ud med nødhjælp og kropsliggør på den vis Pakistans diaspora som handlekraftig, ressourcestærk, trofast og kerende sig om dens oprindelse. Dette er den gode diaspora, Pakistans sønner og døtre, der er flyttet hjemmefra, men mere end lever op til klassiske dyder og forventninger til slægtskab og nære sociale relationer. Men som tiden går, begynder der at opstå revner i den diasporiske relation. Den anerkendelse, som jordskælvet muliggjorde og indstiftede, undermineres på flere fronter. Dels i en dansk nationalstatslig sammenhæng, hvor diasporaens danske statsborgere oplever en træghed fra den danske stats side i forhold til at støtte familier og venner i akut nød. Dels inden for det diasporiske fællesskab, hvor ikke alle kan eller vil yde det samme, hvor nogle er mere altruistiske pakistanske sønner og døtre end andre, og nogle på opportunistisk vis ser ud til at skabe profit på ofrenes bekostning. Hvad der i første omgang var samlende, mobiliserende og bestyrkende i forholdet mellem diasporaen og Pakistan, nemlig katastrofen i Kashmir, bliver således med tiden (temmelig hurtigt endda) et forhold, hvorigennem værdier, dyder og forventninger bringes til diskussion, hvor beskyldninger luftes, og splid mellem fraktioner kommer frem i lyset.

At værdier er til forhandling og jævnligt udfordres, er antropologisk barnelærdom, men hvad Mikkel Rytter viser er, at forhandling og udfordring i en 
pakistansk diasporisk sammenhæng er så udtalt præsent og et så artikuleret mellemværende, at det i forhold til en dansk majoritet kan forstås som et skelsættende etnografisk træk. Det er skælsættende i den forstand, at diasporaen, som det blev tydeligt med jordskælvet, ikke anerkendes som statsborgere, hvis familier og nære relationer vedkommer den danske stat. Det er imidlertid også skælsættende i den forstand, at det betydningsunivers, værdier artikuleres inden for, er så løst, luftigt og foranderligt (som ordet „,upheaval“ $\mathrm{i}$ titlen antyder), at der ofte hersker tvivl og bekymring om, hvilke begivenheder der leder til samling, og hvilke der skaber skel.

Denne pointe behandles også i analysen af studenterrevyen ,En solstråle af håb“ opført af foreningen af dansk-pakistanske studerende (OPSA). Her fremstilles intergenerationelle konflikter og fremmedgørelse inden for en performativ ramme, der, som Mikkel Rytter viser, tillader en italesættelse uden den samme risiko for reelle konflikter. Gennem klicheer som ,de traditionelle bedsteforældre“ i Pakistan, „,de fortravlede og materialistiske forældre“, der arbejdsmigrerede til Danmark, og „de fremmedgjorte børn“, der ikke taler urdu og finder Pakistan primitivt og konservativt, behandles latente spændinger inden for en narrativ struktur, der tilmed muliggør en form for forløsning, idet stykket ender med, at bedsteforældre og børnebørn finder ind til hinanden og dermed bekræfter og konstituerer forestillingen om slægten og de sociale (og pakistanske) relationers værdi.

Analyserne af jordskælvet og teaterstykket er eksempler på klassiske situationsanalyser, og måden, hvorpå Mikkel Rytter får fremskrevet og analyseret ny og tæt empiri, er forbilledlig. Hvad der blandt andet analyseres frem, er fænomenet „kala jaddu“. I en verden, hvor værdier, forventninger, forbindelser og forpligtelser udfordres og forhandles, får ondskab og misundelse stort spillerum. Ulykker, forbandelser, sort magi og onde øjne er, konkluderes det, produktet af en senmoderne præmis, nemlig at adskilte lokaliteter og liv til stadighed føres sammen i form af migration og returmigration, ægteskabsaftaler over landegrænser, sommerferier og studieophold. Hvad der kan opretholdes gennem flyvemaskiner, skypeforbindelser og bevægelig kapital, kan også udfordres og undermineres af de selv samme kanaler. Når splid og ulykke skal forklares, forhindres og hævnes, bliver ordforrådet og remedierne lige så sammensat som diasporaens referenceramme. Det spænder fra „det moderne forfald“, som unge mennesker i vesten udsættes for, til bemalede knogler nedgravet $\mathrm{i}$ haveskure og forbandelser afleveret i moderne boligbyggeri. På den måde er hekseri ikke levn fra en svunden tid, men, vises det, et præsent udtryk i en senmoderne og diasporisk verden.

Mikkel Rytter kommer vidt omkring. Det sker imidlertid uden at være fragmentarisk, men ved at fremanalysere og forbinde en rig og detaljeret empiri indsamlet på mange lokaliteter og over mange år. I denne anmeldelse har jeg 
valgt tre nedslag (jordskælvet, studenterrevyen og hekseriet), fordi de for mig repræsenterer helt nye vinkler på historien om pakistanere i Danmark. Mikkel Rytter behandler også mere alment kendte tematikker såsom migrationsmønstre, arrangerede ægteskaber og terrorfrygt i lyset af 11. september. Dette gøres med større overblik og rigere empiri end nogen anden publikation om pakistanere i Danmark, jeg har læst, og dermed dokumenterer bogen både, hvad vi ved, og giver os helt nye perspektiver på, hvad der former og påvirker diasporiske tilværelser $i$ en senmoderne verden.

Mark Vacher

Ph.d. og lektor

Saxoinstituttets afdeling for Etnologi, Københavns Universitet

\section{BJØRN SCHIERMER (red.): Fænomenologi: Teorier og metoder. København: Hans Reitzels Forlag 2013. 278 sider. ISBN 9788741255996. Pris: 300 kr.}

Det skorter ikke på dansksproget litteratur om fænomenologi og fænomenologiske tænkere. For eksempel har den flittige professor ved Københavns Universitet Dan Zahavi forsynet de danske læsere med op til flere introduktioner til den fænomenologiske idetradition og dens mest fremtrædende tænkere. Derudover publiceres der løbende nye indføringer i blandt andet Martin Heideggers og Edmund Husserls filosofier, som begge typisk regnes med til fænomenologien. På trods af at fænomenologien stortrives på de humanistiske, samfunds-, social- og kulturvidenskabelige uddannelser og institutioner, eksisterer der ikke en samlet introduktion til den fænomenologiske teori og metode, sådan som den benyttes inden for sociologien, antropologien og andre samfunds-, social- og kulturvidenskabelige discipliner. Det råder den nyligt udkomne Fcenomenologi. Teorier og metoder bod på. I bogen præsenterer forskellige forskere fænomenologiske teoriaspekter og metodeudviklinger inden for hver deres respektive fagområde. Bogens styrke er, at den ikke primært er skrevet af fagfilosoffer (som de førnævnte indføringer), men af antropologer, sociologer og urbanitetsteoretikere m.m. Den overordnede hensigt med introduktionen er at vise, hvordan konkrete og hands-on-fænomenologiske analyser kan udføres på specifikke områder. Af den grund er introduktionen velegnet til studerende inden for de førnævnte discipliner.

Bjørn Schiermer, der fungerer som bogens overordnede redaktør, pointerer i sit forord, at de fagfilosofiske indføringer i fænomenologien ikke formår at levere „konkrete impulser“ til blandt andet antropologerne og sociologernes arbejde med fænomenologisk teori og metode. Godt nok er fænomenologien stærkt tilstedeværende på de danske antropologiske og sociologiske uddannelser, tænk 